\title{
Financial Competence of Micro, Small, and Medium Enterprises in Ponorogo
}

\author{
Khusnatul Zulfa Wafirotin \\ khusnafeump@gmail.com \\ Hadi Sumarsono \\ Faculty Economics of Universitas Muhammadiyah Ponorogo
}

\begin{abstract}
The purpose of this study was to know and analyze the accounting capability in an effort to improve financial competence for the Micro, Small and Medium (MSM) entrepreneurs in Ponorogo. The method used was survey, through interview and observation. Accounting competence was viewed from the aspect of sales turnover, capital resources used, net income every month, financial statement preparation, financial statement preparation forms, constraints in the preparation of financial statements, and training that had been participated. The results showed the majority of MSM entrepreneurs in Ponorogo including micro-entrepreneurs and the capital resource had an income per month of $<R p$ 5.000.000,-. Most of them did not prepare for financial statements. The financial statement that was prepared was income statement. Most of them had also not been trained, and financial statement preparation constraints were experienced because they did not understand accounting. MSME financial competence in Ponorogo needed to be improved by accounting training, with the target of being able to prepare financial statements, bankable, increase income to develop the business. Further research was required in the formulation of modules and accounting training for target achievement.
\end{abstract}

Keywords: financial competence, financial statement, MSME.

\section{INTRODUCTION}

Micro Small Medium Enterprises (MMSMEs) currently have a very big role to the economic development in Indonesia. Based on survey results and calculations by Central Bureau of Statistics (CBS) , the contribution of MSME to GDP (without oil and gas) in 2011 was recorded $60 \%$.

Data from Dinas Industri, Perdagangan Koperasi (Indakop) dan Usaha Kecil (Department of Industry, Trade Cooperatives and Small Enterprises) of Ponorogo Regency shows that in 2013 the number of formal industries was 614 units that absorbed 6,429 workers with a production value of 734.17 billion rupiah. As for non-formal industries, there were 19.086 units with a total workforce of 39,541 (Ponorogo in number, 2014).

Most MSMEs do not have the ability to access financing from banks because they have not been able to meet the banking requirements to obtain loans. Many MSMEs are not bankable, because generally MSMEs do not have good bookkeeping, whereas good bookkeeping is one of the requirements to obtain financing from the bank. The same thing was also put forward by Yoshino and Taghizadeh (2016), Tambunan (2008),
Bellefleur, et.al. (2012). The important use of business accounting is for internal purposes, namely to help entrepreneurs in controlling their corporate finances, by raising awareness of the importance of personal finance separation.

According to Teguh (1992) cited by Lilik Indrawati (2006) stated that one aspect of credit analysis conducted by credit institutions (banking and non banking) is the financial aspect. The problem faced by MSM entrepreneurs related to financial aspect is that MSM entrepreneurs do not have accounting knowledge, and many of them do not yet understand the importance of recording and bookkeeping for business continuity (Idrus, 2000; Bellefleur, 2012).

Departing from the explanation above, this research will revolve around efforts to increase financial competence for MSM entrepreneurs in Ponorogo, and the main problem in this study is basic accounting/ financial competence capability analysis for MSM entrepreneurs in Ponorogo. The results of the study by Ardiana, et.al. (2010) indicated that competencies consisting of knowledge, skill and ability simultaneously have a significant effect on MSME performance in Surabaya, but partially only ability and skill have 
significant influence and ability that have the greatest influence.

It cannot be denied that MSME is still a marginal group that is difficult to be associated with modern business and or big business. One indicator of the condition is the difficulty of MSMEs to get access capital from LKF (Lembaga Keuangan Formal/Formal Financial Institutions), especially banking. Indication of the incapability of MSMEs is seen from the low allocation of funds/credit from commercial banks for MSMEs. This is related to the ability of MSMEs in managing finance. Based on Bank Indonesia's survey, one of the obstacles faced by MSM entrepreneurs, seen from the perspective of MSME itself and the banking sector is the ability of MSMEs in managing finance (Andang Setyobudi, 2007). Idrus (2000) also stated that small entrepreneurs do not have accounting knowledge, and many of them have not understood the importance of recording and bookkeeping for business continuity.

Small and Medium Enterprises (SMEs) require bookkeeping skill and easy accounting to help them access financing from banks. So far, many SMEs are unable to access financing from banks because they are unable to meet the banking requirements to obtain loans. Many of our SMEs are not bankable, because most SMEs do not have good bookkeeping, whereas good bookkeeping is one of the requirements to obtain financing from banks. The important use of business accounting is for internal purposes, namely to help entrepreneurs in controlling their corporate finances, by raising awareness of the importance of personal finance separation.

Based on Undang-undang No. 20 Tahun 2008 regarding Micro, Small and Medium Enterprises (MSMEs), there are several criteria used to define the definition and criteria of Micro, Small and Medium Enterprises. Based on total assets and turnover, Micro, Small and Medium Enterprise (MSME) criteria can be classified into 3 types of business. Criteria for classification of this type of business can be seen in Table 1.

Table 1. Criteria of MSME based on assets owned

\begin{tabular}{|c|c|c|c|}
\hline \multirow{2}{*}{ No. } & \multirow{2}{*}{$\begin{array}{l}\text { Type of } \\
\text { business }\end{array}$} & \multicolumn{2}{|c|}{ Criteria } \\
\hline & & Asset & Turnover \\
\hline 1. & $\begin{array}{l}\text { Micro } \\
\text { business }\end{array}$ & Max 50 Million & Max 300 Million \\
\hline 2. & $\begin{array}{l}\text { Small } \\
\text { business }\end{array}$ & $\begin{array}{l}>50 \text { Million - } \\
500 \text { Million }\end{array}$ & $\begin{array}{c}>300 \text { Million - } \\
\text { 2,5 Billion }\end{array}$ \\
\hline 3. & $\begin{array}{l}\text { Medium } \\
\text { business }\end{array}$ & $\begin{array}{l}>500 \text { Million - } \\
10 \text { Billion }\end{array}$ & $\begin{array}{c}>2,5 \text { Billion - } \\
50 \text { Billion }\end{array}$ \\
\hline
\end{tabular}

According to Andang (2007), there are several categories of problems of Micro, Small, and Medium Enterprises (MSMEs), namely:

a. The basic and classic problems of MSMEs are capital, legal entities which are generally nonformal, human resources, product development and marketing access.

b. Advanced problems including the introduction and penetration of export markets that are not yet optimal, lack of understanding of product design in accordance with market character, legal issues related to patents, sales contract procedures and regulations applicable in export destination countries.

c. Intermediate problems, i.e. problems from relevant agencies to solve basic problems in order to be able to deal with further problems better. These issues include financial management, accounting, collateral and limitations in entrepreneurship.

Meanwhile, from the survey results on MSME profiles conducted by Bank Indonesia (Andang, 2007), there are problems and constraints of MSMEs viewed from the perspective of MSME itself and from banking. From the MSMEs' side, some important variables that are still have low performance are: a) Ease of MSMEs in obtaining permit; $b$ ) The ability of MSMEs to manage finances; c) Timeliness and amount of credit acquisition and; skilled workforce.

From banking perspective, low-performing variables of MSMEs are: (a) Financial management capability; (b) Labor skills; (c) Marketing capability; (d) Quality control in production. Muhammad Jafar (2004) stated that the development of MSMEs is essentially a joint responsibility between the government and the community. By looking closely at the problems faced by MSMEs, things that need to be pursued in the future are as follows:

a. The creation of a conducive business climate, among others, by seeking peace and security of business and simplification of business licensing procedures, tax breaks and so forth.

b. Capital assistance, that are to extend the special credit scheme on non-burdening terms for MSMEs, to assist in capital raising through the formal financial service sector, informal financial service sector, guarantee schemes, leasing and venture capital funds.

c. Business protection. Certain types of businesses, especially the traditional business type, which is the business of the economically weak group, should get protection from the government, either through laws or government regulations that lead to a winwin solution. 
d. Development of mutual partnerships between MSMEs, or between MSMEs and large enterprises both domestic and oversea, to avoid monopoly in business.

e. Training. The government needs to improve the training for MSMEs both in the aspects of entrepreneurship, management, finance, administration, knowledge, and skills in the development of its business.

The role of government is needed to assist MSMEs, for 3 reasons (Bellefleur, et.al., 2012): (1) to create productive workers, (2) to improve their productivity and efficiency through small (or large) scale investment in technology, (3) to be more flexible compared to big industry because their smaller size enables then to adjust to the ever changing economic conditions. The central government is concerned to assist MSMEs with the Ministry of Cooperatives and MSMEs, the revitalization of KUR (Kredit Usaha Rakyat/People's Business Credit), and LPDB (Lembaga Pengelolaan Dana Bergulir/Revolving Fund Institutions Fund). Both KUR and LPDB do not provide further managerial assistance to their debtors (Machmud and Siregar, 2010). In fact, MSMEs out of production networks, have weaknesses in their managerial capacity and capability. It is proposed that financial support program should be provided, accompanied by capacity building programs such as business assistance in the form of counseling and advice, business coaching, and training.

\section{METHODS}

The scope of this research was in Ponorogo Regency. Object in this research was all MSM entrepreneurs in Ponorogo Regency, especially micro businessmen who have maximum assets of 50 million and a maximum sales turnover of 300 million in 1 year. Population in this research was all MSM entrepreneurs in Ponorogo. The sampling method used was purposive sampling with the following criteria: (1) MSMEs registered in Indakop Ponorogo Regency, (2) MSMEs are willing to be interviewed and willing to fill out the questionnaire, (3) MSMEs are still actively operationalize the business.

The type of this research was descriptive qualitative, while the data used in this research were primary data and secondary data obtained through observation, interview and questionnaire. The data collection was done by:

a. Observation, the researchers made a direct observation to the business location of MSM entrepreneurs as well as to record the phenomena that occur also to know the condition of the company directly.

b. Interviews directly with MSM entrepreneurs to obtain in-depth information, especially on the preparation of financial statements that had been done, in addition it was also assisted by a questionnaire.

c. Documentation in the form of financial statements owned or already made by MSM entrepreneurs and official sources such as the Central Bureau of Statistics and Dinas Indakop.

The essence of data analysis was the process of reviewing, sorting and grouping data with the aim of composing work hypotheses and turning them into conclusions or theories as research findings. Data was the result of interaction between researchers with data sources. Therefore, data analysis was basically started since data collection began (Winanto, 2016).

Data analysis methods in this study referred to an interactive model consisting of 3 components, namely data reduction, data presentation and drawing conclusions (Miles and Huberman, 1992). This study used a qualitative approach, because according to Kirk and Miller (Moleong, 2001), qualitative research is a particular tradition in social science that is fundamentally dependent on the observation of man and his own region and associated with these people.

This research was a descriptive analytical research, because the data, facts and field findings obtained were developed by providing adequate interpretation on the basis of the results of the analysis of the facts found. This research also used qualitative method, because it described social reality of MSM entrepreneurs in Ponorogo by giving high weight by developing analysis from rational interpretation as input for related parties.

\section{RESULTS}

Ponorogo regency is located in the western region of East Java province with an area of $1,371.78 \mathrm{~km} 2$ which is administratively divided into 21 districts and 307 villages/kelurahan. According to its geographical condition, Ponorogo Regency is located between $111^{\circ}$ $17^{\circ}-111^{\circ} 52^{\prime}$ East Longitude and $7^{\circ} 49^{\prime}-8^{\circ} 20^{\prime}$ 'South Latitude with altitude between $92-2,563$ meters above sea level divided into $2 \mathrm{sub}$ area that are highland area including District of Ngrayun, Sooko, Pudak, Ngebel and 17 other districts are low land area.

Distance of the capital of Ponorogo regency with the capital of East Java Province approximately $200 \mathrm{~km}$ to the northeast and the distance to the state capital is 800 $\mathrm{km}$ to the west. The boundaries of Ponorogo regency are as follows: (1) North: Madiun Regency, Magetan Regency, Nganjuk Regency, (2) East: Tulungagung Regency, Trenggalek Regency, (3) South: Pacitan Regency, (4) West: Pacitan Regency, Wonogiri Regency (Central Java Province).

Administratively, Ponorogo Regency is divided into 21 districts, 307 villages/kelurahan, 947 hamlets/ neighborhoods. To run the wheels of government, it supported by all employees at the district level until 
the village/kelurahan. Ponorogo Regency also has a mineral content. Based on district area, types of minerals are: Ngrayun District contains manganese, ocher and tras $\left(17,792 \mathrm{~m}^{2}\right.$, Slahung District contains zinc, manganese, limestone $\left(6,273 \mathrm{~m}^{2}\right)$, kaolin bentonite $\left(437 \mathrm{~m}^{2}\right)$, zeolite $\left(797 \mathrm{~m}^{2}\right)$, gypsum (26,000 tons), tras $\left(1,305 \mathrm{~m}^{2}\right)$. Bungkal District contains zinc, Sambit District contains tras, District Sawoo contains limestone, Sooko District contains tras, gold, Pulung District contains gold, manganese, tras and sirtu. Sampung District contains limestone and tras. Jenangan District contains gravel. Ngebel District contains gold and tras, while 10 other districts have been no studies so it is remain unknown of their natural resources such as minerals.

Number of respondents who successfully conducted interviews were 50 perpetrators of Micro, Small, and Medium entrepreneurs. Respondent were the ones' name registered in Indakop. Respondents were successfully encountered and interviewed at each business location. Reog craftsmen $24 \%$ or as many as 12 people, bag craftsmen $2 \%$ or 2 people, tile craftsman $20 \%$, or 10 people, printing entrepreneurs $40 \%$ or 20 people, and convection $12 \%$ or 6 people.

There were seven important variables in this study that describes the basic capabilities/competencies possessed by MSMEs in Ponorogo, as many as 50 respondents. The seven variables were (1) sales turnover, (2) capital resource owned, (3) net income per month, (4) preparing financial statements, (5) form of financial statements, (6) training that had been participated, (7) constraints to the preparation of financial statements.

Based on the results of the study showed that sales turnover of MSM entrepreneurs per year shown in Figure 1.

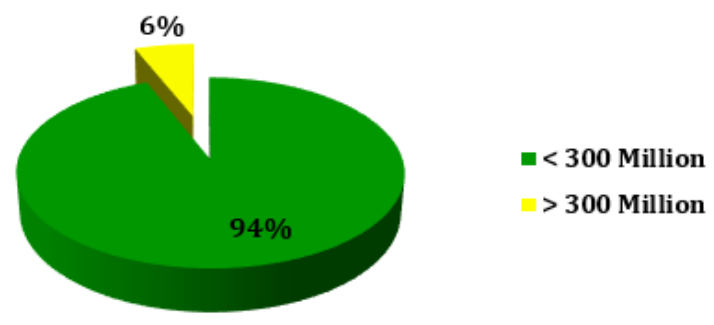

Figure 1. Yearly Sales Turnover

The picture above shows that the majority of MSM entrepreneurs in Ponorogo include micro entrepreneurs in accordance with Undang-undang No. 20 Tahun 2008 regarding MSMEs. This condition reflected that the perpetrators of MSME was indeed required to produce products, especially related to the family economy. Efforts were made to support families, while they were unable to compete in the formal sector, so they were trying in the informal sector. This was understandable because working in the informal sector did not require complicated requirements. The above conditions also indicated that the perpetrators of MSMEs still need a lot of capital to develop their business.

The capital resource used to run the business is shown in Figure 2.

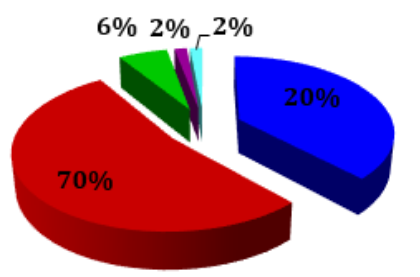

-Bank Loan

-Own Capital

Relative Loan

-Cooperative Loan

Regular Social Gathering

Figure 2. Capital Resource Used

This shows that the capital resource used by MSM entrepreneurs is their own capital and the majority of them have not utilized the facilities of banking. This was influenced by several factors, including the lack of requirements to apply for loans to banks, especially related to the financial statements, because the majority of MSM entrepreneurs did not prepare financial statements for various reasons. In addition, MSM entrepreneurs were still afraid of bank interest, which was high and burdensome. They were more comfortable with their own capital even though the amount was limited which affected the development of business into stagnant, had not shown progress.

The results of this study were in accordance with Yuwono's (2013) study which showed that there are seven factors that inhibit small micro-enterprises in East Java, one of which is financial factors which include difficulty obtaining loans from financial institutions, high loan interest rates from financial institutions, and lack of Assistance from the government. These barriers encourage small micro entrepreneurs to use their own capital.

The results of this study were also in accordance with the results of research by Anton, et.al. (2015) that $80 \%$ of SME make use of their own financial resource as working capital. Banks could not reach most of SME since their lack of ability to compose their business financial plan. Inability of compiling financial plan of SME also has effect on their awareness of business risks. Likewise with Organization for Small \& Medium Enterprises and Regional Innovation, Japan (2008) that at least $60 \%$ of small medium enterprises at present are unable to obtain loans. They are generally self funded. For this reasons, majority of small and medium enterprises are still just microenterprises. As a result, these businesses are not operating effectively or efficiently. 
The monthly net income of MSM entrepreneurs is shown in Figure 3.

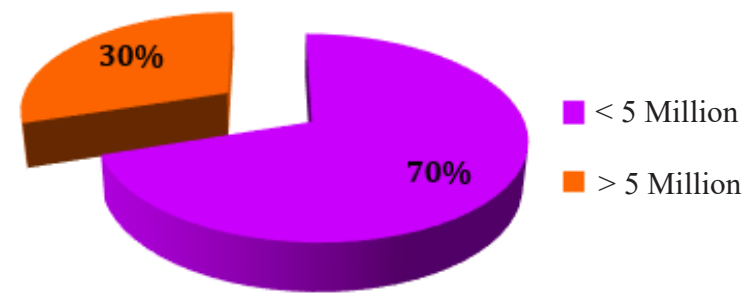

Figure 3. Monthly Income

These results indicate that the monthly income of the majority of MSMEs in Ponorogo is $<\mathrm{Rp} 5.000 .000$, -. Limited amount of capital resulted in limited income which resulted in difficulty to develop business. The majority did not dare to do business development by borrowing to the bank, so the business remained small and certainly very influential on the income earned. Referring to the results of research by Anton, et. Al. (2015) that MSMEs rely on their own capital to finance working capital.

MSM entrepreneurs who prepared the financial statements are shown in Figure 4.
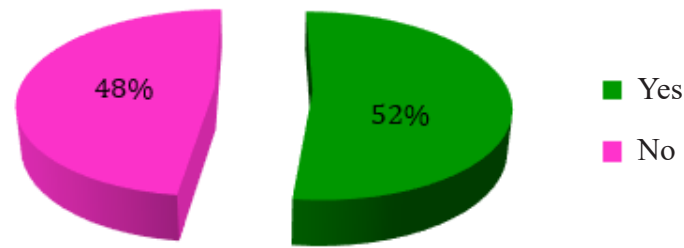

Figure 4. Preparing Monthly Financial Statements

The result of the research indicated that the majority of MSM entrepreneurs did not prepare financial statements, so it was unknown how much assets owned, profit/loss obtained during certain period, and business development was achieved. Besides, by preparing good financial statements, it would be very beneficial for MSM entrepreneurs, especially for the requirements of loan application to the bank. Conversely, if the financial statements were not prepared, then they would not be able to know how their business development in real time, they only knew the development of business based on estimates and wishful thinking. And in the absence of financial statements, they would find it difficult to access credit from banks, so that would affect the development.
The financial statements made by MSM entrepreneurs are shown in Figure 5.

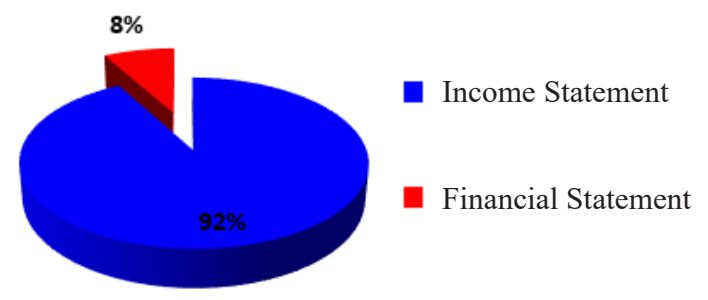

Figure 5. Financial Statement Form

The financial statements prepared were mostly the income statement. A good financial report, would be beneficial for MSM entrepreneurs, especially for the requirements of bank loan application. Conversely, if the financial statements were not prepared, then they would not be able to know how their business development in real time, they only knew the development of their business based on estimates and wishful thinking. And in the absence of financial statements, they would find it difficult to access credit from banks, so that it would affect the development of their business. The use of bank credit needed to be done carefully, as it would increase the risk, therefore the required financial statements were not only Income Statement, but also Balance Sheet, so it could be analyzed how far the capital itself was able to guarantee its debts, and how to use debt to finance the assets.

The training that had been participated by MSM entrepreneurs in Ponorogo is shown in Figure 6.

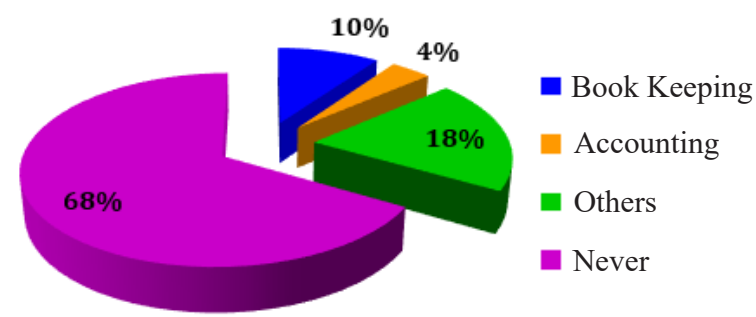

Figure 6. Training that had been participated

The training that has been participated was about bookkeeping, the majority of MSM entrepreneurs had never participated in accounting training. This had an impact on their perceptions of the importance of financial statement preparation related to their business, and the impact on the quality of their financial statements, which ultimately affected the smooth access to credit 
to the Bank, meaning that their financial statements were not yet bankable.

The financial statement preparation constraints experienced by MSM entrepreneurs are shown in Figure 7.
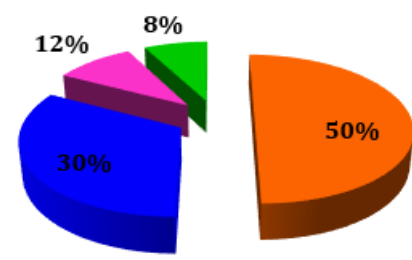

Doesn't Understand Accounting

- Doesn't Have Time

Other

No Constraint

Figure 7. Financial Statement Preparation Constraints

Based on Figure 7 it can be said that the constraints faced as to why not preparing financial statements are because they did not understand accounting and they deemed it not important so they did not take the time to prepare financial statements. This showed the lack of socialization to MSM entrepreneurs related to the importance of preparation of financial statements. While some who had prepared the financial statements because they have been following the bookkeeping training, so they already understood the importance of preparation of financial statements. Although the financial statements they had prepared were not yet completely correct.

From the result of the research, there were 7 (seven) important variables that could describe how the basic financial competence/capability especially in the field of accounting for MSM entrepreneurs in Ponorogo. The seven variables studied included sales turnover, capital resource used, monthly net income, preparation of financial statements, form of financial statements, obstacles in the preparation of statements, training that had been participated.

The role of government is needed to assist MSMEs to improve financial competence (Bellefleur, et.al., 2012, Jafar, 2014), with financial support program should be provided, accompanied by capacity building programs such as business assistance in the form of counseling and advice, business coaching, and training (Machmud and Siregar, 2010). SME leaders should be culturally smart to win the competition creatively (Wijaya, 2014). Increased competence can improve the performance of MSMEs. (Ardiana, 2010). Microcredit and SME finance are often pitched as alternative strategies to create employment opportunities in low-income communities (Bauchet and Morduch, 2012).

Ponorogo Government Regency could help MSM entrepreneurs in terms of: (1) Credit assistance with soft interest, in order to absorb labor by huge number, so as to contribute significantly to the program of poverty alleviation and reduction of unemployment, (2) Providing training to improve a) the financial competence of MSMEs so as to impact their ease in accessing credit from banks (business capital assistance by providing accounting training), b) ways of business management, and c) business assistance, (3) Optimizing the role of KKMB (Konsultan Keuangan Mitra Bank/ Bank Partner Financial Consultant) in fostering and assisting MSMEs who will apply for business credit (4) Socializing profit sharing or venture capital (5) Increasing participation credit guarantee institution for MSMEs who were stumbled because of the requirements of collateral. Hopefully with the implementation of the above assistance, the MSMEs no longer have difficulties in terms of applying for business capital credit from credit channeling institutions, especially banks.

The challenges faced by MSM entrepreneurs are quite large, however, the opportunities faced are also large, so the help and efforts to make them professionals are needed to win the competition.

\section{CONCLUSION}

The conclusions that can be submitted are:

1. Majority of MSME entrepreneurs in Ponorogo who become unit of analysis including micro entrepreneur, capital resource used was their own capital, monthly income majority was $<\mathrm{Rp}$ 5.000.000,-, many did not prepare financial report, financial statements made was Income Statement, most had not been trained, and the financial statement preparation constraints experienced were due to not understand accounting.

2. MSMEs financial competence in Ponorogo needed to be improved by accounting training, with the target being able to prepare financial reports, bankable, increase income, so as to develop the business. Further research is required in the formulation of modules and accounting training for achieving the target.

\section{REFERENCES}

Andang Setyobudi, 2007, Peran Serta Bank Indonesia Dalam Pengembangan Usaha Mikro, Kecil Dan Menengah (MSMEs), Buletin Hukum Perbankan Dan Kebanksentralan, Volume 5, No. 2, August 2007.

Anton, Setyawan Agus; Iza Muzakan; Wajdi Farid Muhammad; Syamsudin; Nugroho Permono Sidiq. 2015. An Assesment of SME Competitiveness in Indonesia. Journal of Competitiveness. Vol. 7, Issue 2, pp. $60-74$. June.

Ardiana, I.D.K.R.; I.A. Brahmayanti; Subaedi. 2010. Kompetensi SDM UKM dan Pengaruhnya Terhadap Kinerja UKM di Surabaya, Jurnal Manajemen dan Kewirausahaan, Vol.12, No. 1, March 2010.

Bauchet, Jonathan and Jonathan Morduch. 2012. Is Micro too Small? Microcredit vs. SME Finance. World Development Vol. xx. pp. xxx-xxx, Elsevier Ltd. 
Bellefleur, Daniel; Zahra Murad; Patrick Tangkau. 2012. A Snapshot of Indonesian Entrepreneurship and Micro, Small, and Medium Size Enterprise Development. For BAPPENAS and USAID. February.

Idrus, 2000. Standar Akuntansi Keuangan Entitas Tanpa Akuntabilitas Publik (SAK ETAP) ; Tantangan dan Kebutuhan Bagi UMKM, www.scribd.com, access date, 01 July 2016

Lilik Indrawati, 2006, Analisis Aspek Keuangan Kredit Modal Kerja Bagi MSMEs, Jurnal Keuangan dan Perbankan, Tahun X, No. 1, Januari 2006.

Machmud, T. M. Zakir and Riski N. Siregar. 2010. Small and Medium Enterprises in Regional Production Networks: An Indonesian Case. In Vo, T. T., D. Narjoko and S. Oum (eds.), Integrating Small and medium Enterprises (MSMEs) into the More Integrate East Asia. ERIA Research Project Report 2009-8, Jakarta: ERIA. pp. 334-373.

Miles, Matthew B dan Hubberman A.Michael.1992. Analisa data Kualitatif Edisi Bahasa Indonesia. Jakarta: UI Press.

Moloeng, Lexy, J. 2001.Metode Penelitian Kualitatif. Cetakan ke-empat belas. Bandung:PT.Remaja Rosda Karya.

Muhammad Jafar, 2004, Upaya Pengembangan Usaha
Kecil dan Menengah (UKM), Infokop Nomor 25 Tahun XX, 2004.

Organization for Small \& Medium Enterprises and Regional Innovation, Japan (SMRJ). 2008. Small \& Medium Enterprise Development Policies in 6 ASEAN Countries. March. www.asean.org

Tambunan, Tulus. 2008. Development of SME in ASEAN with Reference to Indonesia and Thailand. Chulalongkorn Journal of Economics 20 (1), April 2008: $53-83$.

UU No. 20 Tahun 2008 tentang Usaha Mikro, Kecil dan Menengah.

Yoshino, Naoyuki and Farhad Taghizadeh-Hesary. 2016. Major Challenges Facing Small and Medium-sized Enterprises in Asia for Mitigating Them. Asian Development Bank Institute. Working Paper 564. April.

Yuwono, Robby dan R.R. Retno Ardianti. 2013. Analisa Faktor-faktor Pneghambat Pertumbuhan Usaha Mikro dan Kecil Pada Sektor Formal di Jawa Timur. AGORA Vol. 1, No. 3.

Wijaya, Yahya. 2014. Small and Medium Enterprises and The Problem of Inequalities in Indonesia. Presented at Global Ethics Forum in Bangalore, India.

Winanto, Asis Riat. 2016 Pemberdayaan Sektor Informal Di Kabupaten Ponorogo. 